\title{
Aeromonas spp in fish and in continental waters
}

Aeromonas spp em peixes e em águas continentais

\section{Adriana dos Santos Silva1, Ludmilla Santana Soares e Barros ${ }^{2}$, Danuza das Virgens Lima $^{1}$ and Daniela Simões Velame ${ }^{3}$}

\begin{abstract}
Aeromonas are opportunist pathogens of great relevance worldwide, especially in developing countries, and associated to traveler's diarrhea. They are mainly found in water environments and in animals, and related to several infections in humans and animals. There are many cases of human contamination worldwide by several species, especially Aeromonas hydrophila, A. caviae and A. veronii biovar sobria, associated with watery diarrhea and dysentery. In 2010, many new cases of infections by wounds and gastroenteritis, associated to two new species, A. sanarellii and A. taiwanensis were reported. In fact, the genus is pathogenic to humans and animals, with great relevance for public health.
\end{abstract}

Key words: fish, microbiology, water, health

Resumo: Aeromonas são patógenos oportunistas de grande relevância em todo o mundo, especialmente em países em desenvolvimento, e associados à diarréia do viajante. Eles são encontrados principalmente em ambientes aquáticos e animais, e estão relacionados a várias infecções em humanos e animais. Existem muitos casos de contaminação humana em todo o mundo por várias espécies, especialmente Aeromonas hydrophila, A. caviae e A. veronii biovar sobria, associadas à diarréia aquosa e disenteria. Em 2010, muitos novos casos de infecções por feridas e gastroenterites, associados a duas novas espécies, A. sanarellii e A. taiwanensis foram relatados. De fato, o gênero é patogênico para humanos e animais, com grande relevância para a saúde pública.

Palavras-chave: peixe, microbiologia, água, saúde

Autor para correspondência. E. Mail:

Recebido em 15.02.2019. Aceito em 30.03.2019.

http://dx.doi.org/10.5935/1981-2965.20190002

${ }^{1}$ Master's degree at the Universidade Federal do Recôncavo da Bahia (UFRB).

2 Professor at the Universidade Federal do Recôncavo da Bahia (UFRB).

${ }^{3}$ Undergraduate at the Universidade Federal do Recôncavo da Bahia (UFRB). 


\section{Introduction}

Aquaculture and fish farming worldwide

According to the Food and Agriculture Organization (FAO), fish farming is the cultivation of aquatic organisms such as fish, crustaceans, mollusks and aquatic plants. Aquaculture, involving the cultivation of organisms in fresh and sea water under controlled conditions, produces half the amount of fish and mollusks consumed by world populations. According to available data, between 1995 and 2007, fish production has more than tripled through fish farming. Fish farming is segmented according to the class of aquatic organisms cultivated. It may be divided into fish farming, involving fish culture; continental fish farming, involving fresh water fish; sea fish farming, involving sea water fish; mariculture, involving the farming of seaestuary water organisms; algaculture, involving the farming of algae; oyster farming, involving the farming of oysters; shrimp farming, involving the farming of shrimps (SEBRAE ,2015).

World fish production has constantly increased during the last fifty years and fish feeding has had an increment of a $3.2 \%$ mean annual rate, exceeding the growth of world population by $1.6 \%$. Per capita fish consumption increased worldwide at an average of 9.9 $\mathrm{kg}$ in the $1960 \mathrm{~s}$ to $19.2 \mathrm{~kg}$ in 2012 . Whilst excellent development has been due to a combination of population growth, increasing income and urbanization, it has been facilitated by a robust expansion in fish production and more efficient distribution networks.

Fisheries and fish farming have an important role in the eradication of hunger in the world, in health promotion and in the reduction of poverty. In fact, people have never consumed such amounts of fish or were dependent on this food segment for their well-being. Fish is a highly nutritive product, featuring a vital source in protein and essential nutrients, especially relevant to low-income populations. Living on a planet with more than 800 million people suffering from chronic malnutrition and where world population will increase by another two billion to reach 9.6 billion in 2050 (with a concentration of littoral urban areas), mankind must face the great challenge of feeding the planet's populations, coupled to the protection of natural resources for future generations. Approximately 58.3 million people were involved in fish capture and fish farming in 2012 and FAO estimates that fisheries and fish farming guarantee the subsistence of 10 to $12 \%$ of world population.

High fish availability rates are due to China, because of its enormous 
expansion in fish production, especially in fish farming. The proportion of fish production in direct human consumption increased by approximately $71 \%$ in the 1980s and developed to more than $86 \%$ (136 million tons) in 2012. The remaining proportion (21.7 million tons) consisted of non-feed use (fish flour and fish oil). China alone has produced 43.5 million tons of edible fish and 13.5 million of water algae in 2013 (FAO, 2014).

According to FAO, all continents have increased fish production. Since 2008, Asia has produced more farmed fish than captured fish (FAO, 2016). The production of cyprinids has been prevalent in world fish farming, with several carp species ranking first in production. Although the Nile tilapia ranks fourth, it is the species with great relevance worldwide. Brazilian fish farming is represented by tilapias, with $43 \%$, tambaqui, with $23 \%$, and tambacu and tambatiga, with $15 \%$. The former contributes $35 \%$ of Brazilian fish farming production (SEBRAE, 2015).

The farming of fish in Brazil is constantly increasing. There was a $10 \%$ growth for 2016 (FAO, 2016). According to the Brazilian Association of Fish Farming, such results rank Brazil as the fourth in tilapia culture worldwide. China ranks first, with 1.8 million tons, followed by Indonesia, with 1.1 million, and Egypt.
The Philippines and Thailand are below Brazil in production (PEIXE-BR, 2018).

Fish represents approximately $17 \%$ of animal protein ingested by world population and $6.7 \%$ of all protein intakes. In fact, fish provides more than 3.1 billion people with almost $20 \%$ of mean animal protein per capita. The significant growth in fish consumption in people's diet worldwide is related to healthier, diversified and nutritive food. Fish is a rich protein source, with high biological value, rich in non-saturated fatty acids, vitamins and minerals as healthy consumption options. Due to their nutritional features, they may have an important role in diet correction against obesity and cardiovascular diseases (DE OLIVEIRA SARTORI, 2012; FAO, 2014; FAO, 2016, BRAVO, 2016).

\section{Fish farming in Brazil}

Fish production and consumption have increased significantly in Brazil during the last decades. Owing to its climatic and territorial conditions and to its hydric potential and favorable conditions in the construction of fish tanks and dams, Brazil has an excellent capacity for the development of fish farms. Several research works have shown that fish farming had the greatest development between 2004 and 2014, when compared with beef production (KUBITZA, 2012, 2015). Among the several species farmed 
in Brazil, the tilapia is the main species, with a $14.2 \%$ mean production per annum. According to IBGE, the tilapia was the fish species with the highest growth rate in 2014. It represents $41 \%$ of fish production, with a $17.3 \%$ increase over 2013 .

Fish production in 2014 reached $\mathrm{R} \$$ 3.87 billion, of which $90 \%$ derived from fisheries, or rather, 70.2 and $20.5 \%$ from fish and shrimp farms, respectively. Brazilian fish farms produced 474.33 thousand tons of fish in 2014, with special reference to the northern region in 2013 and 2014. The state of Rondônia produced 75.02 thousand tons of fish (IBGE, 2014).

Fish production grew constantly during 2016, with 640,510 tons in 2016, or rather, a $4.4 \%$ increase when compared to that in 2017. Moreover, in 2017, growth reached $8 \%$ with 691.7 thousand tons. The tilapia is the most farmed fish in Brazil, reaching $51.7 \%$ of Brazilian fish farming, or rather, 357,639 tons in 2017 (IBGE, 2014; IBGE, 2016; CAMPOS, 2017; PEIXE-BR, 2018).

The state of Paraná is the greatest producer of tilapia in Brazil, with $94 \%$ of total fish production. Tilapia makes up 95\% of the production in the state of São Paulo. The third national producer is Santa Catarina (74\%), followed by Minas Gerais, (95\%) and Bahia (81\%). The five states together produce $64.9 \%$ of national production (PEIXE- BR, 2018).
The growth of fish farming in Brazil has triggered the establishment of catch-and-pay fishing in fish ponds which has developed constantly and is currently a big-profit entrepreneurship, with job hiring and large incomes for the municipalities with the activity, together with catch-andrelease fishing. Started in the 1970s, catchand-release fishing is different from catchand-pay fishing (ANDIROBA, 2017; CAVALETT, 2006; SCHORK et al., 2010).

Brazilian aquiculture tourism has always been associated with catch-and-pay fishing. As a fun activity, catch-and-pay fishing is inserted within the aquaculture production chain due to the network involving fish, rations and equipments, with great contributions to the development of Brazilian aquaculture. Catch-and-pay fishing became big business and triggered the fast growth of fish chain and the establishment of several enterprises for its practice, especially in the states of São Paulo, Paraná and Espírito Santo (ANDRADE, 2007).

Research on fish farming in Brazil and in the state of Bahia has shown that the Nile tilapia is the most produced fish in the region (KUBITZA et al, 2012; KUBITZA et al, 2015). Brazil is one of the seven greatest producers of tilapia worldwide, with a production of more than 250,000 tons. In fact, it is one of the most produced 
species (BRASIL, 2014). However, people living in the Recôncavo da Bahia area and who frequent the region's catch-and-pay fish ponds evidence that several other fish species are involved, such as tambaqui (Colossoma macropomum), tilapia (Oreochromis niloticus), catfish (Siluriformes), surubim (Pseudoplatystoma fasciatum), pacus (Piaractus mesopotamicus), carps (Cyprinus carpio) and piaus (Leporinus friderici).

The growth of fish farming in Brazil triggered concern on the quality of the product at the financial and microbiological levels. The products may increase natural microbiological loads and more resisting bacteria which may be associated with pathogenic microorganisms for fish. Aeromonas, a fish pathogen, may bring about economic liabilities and health risks for people who may consume the fish. Another issue associated with fish farming is the excessive use in commercial antibiotics which may produce resistant strains, affecting fish and animals (SILVA et al., 2010; CARNAHAN; JOSEPH, 2005).

\section{Food- and Waterborne} Diseases (FWDs) and contamination-

\section{indicator microorganisms}

FWDs are generally related to bad hygiene-sanitary habits and to crossed contamination by infected handlers and contaminated utensils (DE ASSIS, et al.,
2011). According to the Ministry of Health (2014), there are more than 250 types of FWDs. They are currently one of the causes of diseases and deaths worldwide. In fact, FWDs are a serious health issue in Brazil and throughout the world. Epidemiologic research in Brazil, undertaken by the Ministry of Health, showed that 10,666 FWD outbreaks occurred between 2000 and May 2015, of which 154 died. Outbreaks had a high prevalence in the southeastern region of Brazil, with $39.9 \%$ of cases. In the northeastern region, prevalence reached $14.7 \%$ and featured the third region with the greatest number of outbreaks (BRASIL, 2015).

FWDs are diseases caused by the ingestion of contaminated food or water with microorganisms or toxins produced by them. Several pathogens may be related to the emergence of FWDs and may inhabit one or more persons, depending on its virulence.

One case may be considered an outbreak as, for instance, Clostridium botulinum and Escherichia coli O157: H7. When these microorganisms contaminate food, they do not change neither its characteristics nor its smell or taste. Consequently, contamination is highly difficult to detect. Several studies evidence that the above factors occur because the microorganisms' infecting dose is smaller 
than the amount required to degrade them (OLIVEIRA, et al., 2010).

One of the factors that may be linked to outbreaks of diseases borne by water and food is the costume of eating in bars or restaurants which has become a trend nowadays. The habit is highly potential in the transmission of diseases borne by food to consumers. Food processing may involve crossed contamination due to manipulation (SOUZA, 2008).

Most of the notified FWD etiological agents were not detected. Salmonella spp. was the most detected microorganism out of those identified. However, there are other indicating microorganisms used to evaluate the microbiological quality of water and food (BRASIL, 2015). When indicator microorganisms are isolated in food and water samples, they possibly pinpoint fecal-originating contamination. They may also indicate pathogenic microorganisms or inadequate hygiene and sanitary conditions during processing, production or storage, or with regard to shelf-life. It should be underscored that total and thermotolerant coliforms, mesophyll aerobic microorganisms and psichrotrophic aerobic microorganisms are included in the group of indicator microorganisms (FRANCO; LANDGRAF, 2004). According to Ribeiro (2008), the genus
Aeromonas may be used as an indicator of drinkable water.

Correct procedures in the handling of fish guarantee microbiological quality of fish between its capture and its consumption. Several studies have shown the water's microbiological quality of fish ponds may affect the microbiological quality of fish and byproducts. In fact, fish have been associated to human diseases since they are the vectors of pathogen microorganisms, considered an issue in public health. FWDs are associated to fish, hygiene and sanitary conditions, and the handlers' lack of information on good handling practices (FAO, 2011; COSTA, 2016; SOARES; GONÇALVES, 2012).

\section{Total and thermotolerant coliforms}

Total coliforms are classified as non-sporulating Gram-negative bacilli, made up of bacteria of the family Enterobacteriaceae which ferment lactose by producing gas bubbles when incubated at $35-37^{\circ} \mathrm{C}$, for $48 \mathrm{~h}$. Thermotolerant coliforms are a subgroup which includes microorganisms that ferments lactose up to $44-45^{\circ} \mathrm{C}$. The bacterium Escherichia coli is the main representative of the subgroup (FRANCO; LANDGRAF, 2004).

Water is colonized by several microorganisms, especially exogenous agents derived from human and animal fecal material, such as total coliforms, thermotolerant coliforms and enterococci. 
Genera Escherichia, Enterobacter, Citrobacter and Klebsiella are included in this group. There are also agents which are part and parcel of the water's natural microorganisms, among which the motile bacteria of the genera Aeromonas and Pseudomonas may be mentioned (RIBEIRO， 2008; $\quad$ FRANCO; LANDGRAF, 2004).

Whereas the presence of total coliforms indicates hygiene conditions, thermotolerant coliforms demonstrate fecal contamination and are used to evaluate the lack of hygiene-sanitary conditions. Thermotolerant coliforms in food reveal high rates of $E$. coli and thus the food's contamination and sanitary quality levels (FRANCO; LANDGRAF, 2004). Moreover, E. coli in processed food reveals that the latter was probably contaminated after processing and that improper handling and hygiene practices were employed (DE SOUSA LIMA et al., 2007).

Coliforms are contaminationindicating agents through fecal contamination and pinpoint hygiene and sanitary conditions of food and water. Although coliforms do not belong to the natural intestine microbiota of fish, they have been frequently isolated from their gastrointestinal tract. Consequently, the microbiological assessment of fish may reveal the water's microbiological conditions in which fish live (LORENZON et al, 2010). Several research works have shown that thermotolerant coliforms and total aerobic microorganisms in fish ponds are a serious health issue. A strict hygiene control during management and handling of the fish farm products should be maintained to avoid the transference of the bacteria from water to fish and their byproducts (LORENZON, 2010; SOUZA 2011).

A study on fish and on water from catch-and-pay fish ponds was undertaken in the microbasin of the Córrego Rico in the state of São Paulo, Brazil, to determine the number of total and thermotolerant coliforms, positive coagulase Staphylococcus and bacteria of the genus Salmonella in the muscle, surface tissue and gastrointestinal tract. Results revealed total and thermotolerant coliforms and Salmonella in one of the samples, without any contamination by positive coagulase Staphylococcus. It has been concluded that fish may be a vector of crossed contamination since the skin and the gastrointestinal tract may be a source of contamination for the fish muscles (LORENZON et al., 2010).

Santos et al. (2012) evaluated the water's microbiological quality and tissue changes in the gills of the Nile tilapia (Oreochromis niloticus) and of the hybrid tambacu (Colossoma macropomum female 
$\mathrm{x}$ Piaractus mesopotamicus male) in the municipality of Itapecuru-Mirim MA Brazil. The microbiological analysis of water revealed pollution by total coliforms, Escherichia coli and heterotrophic bacteria. Several Gram-positive and Gramnegative bacteria were detected in the gills. Monitoring of water quality is an important factor to guarantee the production of fish with hygiene and sanitary quality for human consumption (LORENZON et al., 2010).

\section{Escherichia coli}

Bacteria of the genus E. coli are facultative Gram-negative anaerobes of the Enterobacteriaceae family, rod-shaped, motile or immotile by peritrichous flagella, with respiratory and fermentative metabolism. They trigger lactose, negative oxidase, positive catalase, non-sporulating, and grow in non-enriched media. The gastro-intestinal tract of humans and hotblood animals are E. coli's primary habitat. Although the strains that colonize human intestine tract are not harmful, some of them are pathogenic to humans and may cause diseases such as urinary infections, diarrhea, hemorrhage colitis and hemolytic-uremic syndrome (FRANCO; LANDGRAF， 2004; GERMANO \& GERMANO, 2008; SOUZA, 2008; SANTIAGO et al., 2013).

E. coli strains are classified by antigenic differences (serum type) and virulence factors. Antigen $\mathrm{O}$ characterizes the serum group and flagellum $\mathrm{H}$ characterizes the serum type. Flagellumless strains are identified as non-motile (NM). Some strains have the capsular antigen $\mathrm{K}$ for classification too (GERMANO \& GERMANO, 2008). Several research works have shown that there are more than 180 different $E$. coli serum groups. A co-relationship exists between serum group and virulence (MENG et al., 2001; FRANCO; LANDGRAF, 2004; CAMOS; FRANZOLIN; TRABULSI, 2004).

Although most E. coli strains are harmless to the host, others are pathogenic and cause diarrhea, classified according to virulence, pathogenicity mechanisms, clinical and serological symptoms. The main E. coli pathotypes which cause diarrhea in humans are enteropathogenic $E$. coli (EPEC), enterotoxigenic E. coli (ETEC), enteroinvasive E. coli (EIEC), enteroaggregative $E$. coli (EAEC) and enterohemorrhagic E. coli (EHEC), including E. coli O157: H7, the main groups of pathogenic E. coli associated with food intake (FRANCO; LANDGRAF, 2004; GERMANO \& GERMANO, 2008; SILVEIRA et al., 2013; VOLKWEIS et al., 2015).

In fact, Escherichia coli has been used since 1892 as an indicator of fecal contamination in water and food, and of 
enteropathogens

(FRANCO;

LANDGRAF, 2004). According to FAO

(2013), E. coli is a non-native microorganism for fish and is not considered a participant in fish microbiota. Consequently, the microorganism's isolation in food may be associated with fecal contamination of the site where fish are caught, by crossed contamination during transport and handling process and by utensils or ice in contact with the fresh fish. This boils down to the fact that its presence indicates unsatisfactory hygiene and sanitary conditions (AGNESE et al.,2001; FRANCO; LANDGRAF, 2004; FAO, 2010; SANTIAGO et al., 2013; FERREIRA,2014).

Ferreira (2014) analyzed fish and ice samples in the state of Maranhão, Brazil, and detected E. coli and thermotolerant coliform in the ice. The presence of the microorganism in ice shows that the water used had direct or indirect contact with fecal contamination and thus serious flaws during the preparation of the product, due to inadequate hygiene conditions, crossed contamination with utensils and equipments or their inadequate cleansing and disinfection. The above is a health risk factor for consumer since the bacterium has five groups which are pathogenic to humans. Another research in the town of Cruz das Almas BA Brazil revealed
Escherichia coli in fish sampled in the municipal marketplace, resistant to the antibiotics erythromycin 08 (100\%), amikacin 02 (25\%), ampicillin, cephalothin and tetracycline 01 (12.5\%) (BARRETO et al, 2012).

Enterohemorrhagic E. coli has several serum types, particularly O157: H7, widely known and of great relevance for public health. In the 1980s, Escherichia coli O157: H7 was classified as a foodoriginating pathogen. Several outbreaks caused by the etiological agent E. coli O157: H7 occurred during this period (KATSUYA et al., 1998). The serum type O157: $\mathrm{H7}$ is a highly relevant microorganism due to its association with human pathologies. The infection caused by the serum type is associated with the development of hemorrhagic colitis, diarrhea with blood, and uremic hemolytic syndrome (SOUZA, 2008). Escherichia coli O157: $\mathrm{H} 7$ is currently considered an emergent pathogen which may be isolated anywhere and is associated with food contamination. Its resistance to adverse environments has been widely discussed (QUESADA; ARIAS; CHAVES, 2003).

\section{Mesophilic aerobic microorganisms}

Mesophilic aerobic microorganisms are multiplying bacteria at temperatures ranging between 10 and $45^{\circ} \mathrm{C}$, with best growth temperature at 30 and $40^{\circ} \mathrm{C}$. Psichrotrophic aerobic microorganisms 
grow in food under refrigeration $\left(0-7^{\circ} \mathrm{C}\right)$, with best growth temperature above $20^{\circ} \mathrm{C}$ (SILVA et al., 2007). Total counting of mesophilic aerobic microorganisms on plates is a method which fails to identify species types and is a general indicator of bacterial populations in food. Although Brazilian law does not have any reference for fish, the microorganisms should be researched to warrant food quality. The method is employed to obtain general information on the quality of products, production practices, quality of prime matter used, processing and handling conditions and products's shelf-life (SILVA et al., 2007; LIBERATO, 2005.).

Tally of aerobic mesophylls is used as a cleansing indicator and a control and monitoring of production processes. In other words, counts are a source of evaluation on safe handling of the product and food security. Counts of thermophile microorganisms assess the deterioration degree of refrigerated food or of thermaltreated food (CARVALHO, 2005).

Ritter et al. (2012) studied the hygiene-sanitary quality of barred sorubim (Pseudoplatystoma fasciatum) from fish farms and isolated Aeromonas strains and mesophyll aerobic heterotrophic bacteria. High bacteria counts of the genus Aeromonas spp. were detected, with increasing concern, since the genus is implicated in human pathologies. The authors have recommended control water and fish quality for consumption.

\section{Microorganism Staphylococcus aureus}

Staphylococcus belongs to the family Micrococcaceae. The Grampositive bacteria, facultative anaerobic agents, are sphere-shaped and may occur isolated, in pairs and in irregular groups. They are non-motile, non-sporulating and chemo-organotrophic bacteria. Best growth temperature ranges between $30-37^{\circ} \mathrm{C}$. $S$. aureus strain grow in $\mathrm{pH}=7$, with best temperature at 3 (SANTOS et al., 2007).

$S$. aureus is a pathogenic agent which has caused several food-originating intoxication outbreaks. When the microorganisms are in favorable growth conditions, they may be related to opportunist infections. Staphylococcus aureus causes food intoxication through its enterotoxins released during the bacterium's growth process in food. Enterotoxins may occur anywhere since its habitat is widely distributed in nature. The microorganism endangers health due to its toxin-infection potential (Franco; Landgraf, 2004; Germano PML; Germano, 2008).

Staphylococcus aureus is a human pathogen which causes several diseases, featuring intense intestine infection with vomiting, diarrhea and even skin infections. The bacterium is one of the most relevant causes of food infection 
worldwide. The intake of colonized food with enterotoxin production triggers food intoxications (DE SOUSA LIMA et al., 2007). Staphylococcus aureus occurs in animal-derived uncooked food. The latter requires a strict handling process to guarantee food safety. In fact, high rates of staphylococci in uncooked food made from animals foreground efficacious processes for safety. Since humans are an important reservoir for recontamination after an infectious process, people may be the cause of food contamination (SOUSA, 2008).

$S$. aureus, often pinpointed as the main agent in outbreaks of staphylococci diseases, has been isolated from skin surface, human mucus and food. Industries consider it a bio-indicator of a product's sanitary quality (FRANCO; LANDGRAF, 2004). It is, in fact, one of the most discussed pathogens in research on food microorganisms responsible for intoxication outbreaks. Staphylococcus enterotoxin differs from other microorganisms due to its thermal stability. Since it remains active even after cooking, $S$. aureus favors the installation of intoxication conditions due to food. It is an issue in public health (FRANCO; LANDGRAF, 2004; ROCHA et al. 2013).

The literature and statistical data in Brazil and worldwide abound with registers on fish contamination by $S$. aureus. Contamination indicates inadequate handling and is directly related to the handlers' personal hygiene and to utensils used. Intoxication by staphylococcus occurs by toxins released in the organism. It develops on the food surface and releases toxins, causing nauseas, vomiting, belly aches and diarrhea within a short incubation period, 1 - $6 \mathrm{~h}$ after the ingestion of contaminated food. Several studies have revealed that good production practices, good sanitary conditions and temperature control are basic to avoid contamination, the proliferation and production of toxins, especially in pre-cooked fish (GERMANO \&GERMANO, 2008; ROCHA et al. 2013; DE PAIVA SOARES et al., 2012.

Fish is a product with great susceptibility to microbial proliferation due to its physiological characteristics, such as $\mathrm{pH}$ close to neutral, high water activity in the tissues and great nutrient availability. Consequently, inadequate hygiene conditions during production phases associated with favorable conditions may provide the undesired growth of microorganisms (DE PAIVA SOARES et al., 2012; ROCHA et al. 2013). Rocha et al. (2013) quantified positive coagulase staphylococci in the fillets of tilapia (Oreochromis niloticus) sold in the town of Currais Novos RN Brazil, and registered that all samples proved positive for $S$. 
aureus. Moreover, counts were above standards established by Brazilian law in $73.3 \%$ of cases. This fact proved inadequate hygiene and sanitary conditions of the material analyzed. Muratori et al. (2007) evaluated Escherichia coli and Staphylococcus aureus in fish farm handlers and registered that they may vector Escherichia coli and Staphylococcus aureus to farmed fish, premises and fishing environment.

Viana (2016) assessed the microbiological quality of 16 samples of tambaqui sold in the fair of the town of Ariquemes RO Brazil, and reported that all samples were contaminated with total coliforms. S. aureus was isolated in $37.5 \%$ of samples, with higher rates than allowed. The author concluded that the analyzed tambaquis were exposed to contamination due to deficient sanitary conditions.

\section{Taxonomy and classification of the} genus Aeromonas

The species Aeromonas was identified by Zimmermann some 120 years ago and had several taxonomic classifications. Although several new species were described, identification techniques were imprecise and it was difficult to distinguish truly new species (EUZÉBY, 1998; IGBINOSA et al, 2012). In fact, Aeromonas were classified differently, such as Proteus, Escherichia, Pseudomonas, Vibrio, genus Aeromonas, family Pseudomonadaceae" (SILVA et al., 2010).

The genus Aeromonas has recently been subjected to an extensive nomenclature and taxonomic revision. Aeromonas were first allotted to the family Vibrionaceae. After the rise of phylogenetics coupled to genetic and molecular research, it became clear that the genus did not have the same characteristics as other microorganisms in this family. Consequently, a new family called Aeromonadaceae was established (JANDA \& ABBOT, 2010; SILVA et al., 2010). There are currently 31 acknowledged species of the genus Aeromonas, with 12 sub-species. A. veronii, A. caviae and $A$. hydrophila are species usually related to human pathologies (PIOTROWSKA; POPOWSKA, 2015; TAVARES; CERESER; TIMM, 2015). One may perceive that recently Aeromonas have been subjected to different classifications. At present they are taxonomically classified as (CARNAHAN; JOSEPH, 2005).

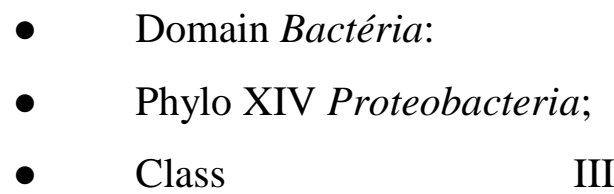

Gamaproteobacteria;

- $\quad$ Order XII Aeromonadales;

- Family I Aeromonadaceae ;

- Genus I Aeromonas 
Bacteria of the genus Aeromonas are classified according to multiplication temperature and motility. The first group comprises mesophyll heterogenic species. A. hydrophila, A. caviae, A. sobria and others are pathogenic agents to humans and fish. They are motile species, with multiplication temperature ranging between 5 and $45^{\circ} \mathrm{C}$, with best temperature at $28^{\circ} \mathrm{C}$ (TAVARES; CERESER; TIMM, 2015; SILVA et al. 2010). The second group comprises psychrophile non-motile bacteria, with species $A$. salmonicida and A. media. A. media fails to multiply at $37^{\circ} \mathrm{C}$ and $A$. salmonicida does not multiply at temperatures lower than 22 and $25^{\circ} \mathrm{C}$. The latter is not pathogenic to humans but may cause furunculosis in fish (SILVA el al., 2010). Two new Aeromonas species of clinical importance, Aeromonas sanarellii and Aeromonas taiwanensis, were discovered in 2010. They were classified from strains isolated from the wounds of a Taiwan patient. Whereas the species, isolated from waste water and in environmental samples, were also identified in Portugal, the A. taiwanensis was isolated in Israel from the faeces of a patient with diarrhea and in a residue lake (SENDEROVICH et al., 2012).

Bacteria of the genus Aeromonas are classified as anaerobic facultative Gram-negative rods, 0.3-1.0 $\mu \mathrm{m}$ diameter and 1.5-3.5 $\mu \mathrm{m}$ length. Isolated bacilli or coccobacilli may be found in pairs or in short chains, forming oxidase and positive catalase reactions (SILVA et al., 2010, RIBEIRO, 2008). The literature reveals best growth temperature at $30^{\circ} \mathrm{C}$, with ranges between $4^{\circ} \mathrm{C}$ and $45^{\circ} \mathrm{C}$, respectively minimum and maximum growth rates, and $\mathrm{pH}$ between 4.5 and 9.0. (RIBEIRO, 2008; CARNAHAN; JOSEPH, 2005).

As a rule, these bacteria are motile. In fact, they are provided with either polar monotrichous flagella or lateral flagella. Several authors report that juveniles may develop peritrichous flagella. Aeromonas have other types of structure, such as pilli, $S$ layer and capsule, which cause their pathogenicity (JANDA; ABBOTT, 2010; CARNAHAN; JOSEPH, 2005; SILVA et al., 2010).

Although most Aeromonas are encapsulated and non-sporulating, they produce a vast range of exo-enzymes which establish their degree of pathogenicity and virulence. The biochemical factors produced by Aeromonas are glucose-fermenting microorganisms, with the production of acid, with or without gas, due to denitrification. In the absence of oxygen, bacteria transform nitrate into nitrite and are not inhibited by the vibriostatic 2,4diamino- 6,7-diisopropylpteridine agent 
(O/129) (JANDA; ABBOTT, 2010; CARNAHAN; JOSEPH, 2005; SILVA et al., 2010).

The genus Aeromonas is associated with water environments and bacteria strains are isolated from rivers, lakes, sea water (estuaries), fish tanks and every type of drinking water, even underground ones. They may also occur in residue and sewerage water (CARNAHAN; JOSEPH, 2005; SILVA et al., 2010; JANDA; ABBOTT, 2010; MARTINO et al., 2011).

Several studies have reported Aeromonas spp. in drinkable water and in river-sea waters and fish ponds. They are mainly extant in the supply water system, with serious issues in public health. In fact, Aeromonas indicates environmental quality since several species are pathogenic for humans. Other studies have shown that Aeromonas strains may survive in climatic variations and in different physical and chemical water conditions (FIORENTINI, C. et al., 1998; IGBINOSA et al., 2012; RIBEIRO, 2008; SILVA et al., 2010; JANDA; ABBOTT, 2010).

According to Ribeiro (2008), the literature has few reports on the isolation of Aeromonas spp. in the soil. Several studies demonstrate that Aeromonas may multiply and preserve their virulent characteristics in the soil which, in turn, may be a possible reservoir of the bacterium, causing inflections in human beings (BRANDI et al., 1996 RIBEIRO, 2008; JANDA; ABBOTT, 2010).

Aeromonas spp. may be isolated in vertebrates and in insects. Specialized literature shows that bacteria may cause serious diseases in animals and in human beings. Consequently, animals involved within the Aeromonas's dissemination cycle in the environment may transmit the pathogens to humans. In fact, pathogenic strains have been detected in carcasses and animal meat consumed by humans. It may also be associated to wound infections from bites by infected animals or to generalized infection (septicemia) in immune-depressed patients (RIBEIRO, 2008; JANDA; ABBOTT, 2010).

However, several studies have revealed that the pathogenicity mechanism of Aeromonas ssp. is still to be defined. Virulence is multifactorial since Aeromonas produces several extracellular enzymes (amylase, hemolysin (aerolisines), cytotoxins, gelatinase, enterotoxins, proteases, lipase, leucocidines, phospholipases, chitinase, nuclease, lecitinase, elastases, DNAses, adesines, cholinesterase and endotoxines) that affect the virulence degree of each species. They are directly related to the disease's pathogenesis causing several virulence factors (RODRIGUEZ et al., 2007; NAM; JOH, 2007; PEIXOTO, et al., 2012). 
Several factors may cause the development of diseases by Aeromonas infection. They are capable of causing diseases in humans. In fact, water and food are important vector agents. Several studies have shown that animal-originating food is one of the main factors for the epidemiology of pathogenic species for humans (OTTAVIANI et al., 2011; TAVARES; CERESER; TIMM, 2015).

A study conducted in Italy with 142 Aeromonas strains from patients suffering from diarrhea caused by food and surface water revealed that $A$. hydrophila and $A$. caviae were the most detected species in clinical samples, whereas A. salmonicida was commonest in food. The authors perceived that 86 strains were positive for more than one virulence factor. Data show that Aeromonas may cause disease in humans and that food and water are the main vectors for their development (OTTAVIANI et al., 2011).

A study on water from a Spanish water supply company was performed with 132 samples from which 35 isolates of $A$. caviae and A. media were identified. Identified strains revealed more than one virulence factor correlated to genes with high pathogenicity levels. The study also showed that it was still possible to recover Aeromonas strains at $14^{\circ} \mathrm{C}$, indicating that the proliferation of the bacterium may also occur at low temperatures. Results demonstrate the direct or indirect transmission of the microorganism to the population, or rather, by the intake of contaminated water or by using contaminated water in food cooking (MANUEL PABLOS et al., 2009; SILVA et al.,2010).

\section{Bacteria of the genus Aeromonas spp. associated with human pathologies}

Infections by Aeromonas is a public health issue since outbreaks have economic consequences and personal and public costs associated with the impact of contaminated water in the water environment. Several studies show that the prevalence of Aeromonas-caused infections may be underestimated in developing countries due to subnotification and that the exposure to animal-derived pathogenic agents may occur with great frequency (IGBINOSA et al., 2012). According to Igbinosa et al. (2012), Aeromonas species are bacteria that may occur in land and water environments. Several research works have indicated that the microorganism is a pathogen causing serious concern in public health due to its resistance to antibiotics and to several virulence factors associated to infections and other human pathologies such as gastroenteritis, soft tissue disorders, muscle infections and 
septicemia.

A. hydrophila are pathogenic Gram-negative bacilli for aquatic animals and an opportunist pathogenic for humans. Humans are infected through skin wounds which are the entrance for the microorganism, or through ingestion. The latter cause gastroenteritis due to the intake of contaminated water or food originating from animals (fish, seafood, beef) or from vegetals. Aeromonas is a microorganism that occurs in all environments, or rather, in sea water, waste water and fresh water (FDA, 2009; GONÇALVES, 2012; SILVA et al.,2014; LATIF-EUGENÍN; BEAZHIDALGO; FIGUERAS, 2016).

Aeromonas are opportunist pathogens with great relevance for public health since they are potential causes of gastroenteritis and extra-intestine infections. Aeromonas-caused wound infections develop into cellulitis which is another public health concern related to septicemia, associated with wound infection or secondary to systemic diseases, such as hemolytic uremic syndrome, peritonitis, pneumonia and others (SILVA et al.,2014; CHAN, 2000). Recent studies have revealed that extraintestine infections may also occur in healthy people (IGBINOSA et al., 2012).

Aeromonas hydrophila, A. caviae and $A$. veronii biovar sobria may be underscored as human pathogens among the clinical manifestations in Aeromonascaused infections. A. hydrophila is associated with watery diarrhea and dysentery. The bacterium particularly attacks immune-depressed people and may develop into generalized infection. Neonatal patients may develop a gastrointestinal disease (FDA, 2009; GONÇALVES, 2012; JANDA; ABBOTT, 2010; LAVIAD; HALPERN, 2016).

Mukhopadhyay (2008) studied Aeromonas as a pathogen which causes extra-intestine infections and reported that all Aeromonas-infected patients also had subjacent diseases, such as hepatic disease, diabetes mellitus and pneumonia. The analysis also remarks on the relevance of the isolation of A. hydrophila from extraintestinal samples. In fact, the microorganism causes serious infections in immunocompromised patients and in immunocompetent people.

The literature shows divergent views with regard to the etiology of several types of gastroenteritis related to infection by Aeromonas. In fact, there are only few reports on the outbreak of gastroenteritis caused by Aeromonas and their presence in feces in asymptomatic individuals. On the other hand, several research works have reported that Aeromonas is the etiological agent of gastrointestinal diseases and remarks that this is due to certain virulence characteristics of each species that cause 
infection and disease (WU, et al., 2012; JANDA; ABBOTT, 2010).

A study with 101 patients hospitalized with diarrhea, performed in Pudong, Shanghai, revealed that 71 patients had diarrhea caused by Aeromonas infection. Moreover, there was a high occurrence of Aeromonas-caused infection. Most strains had virulent genes, with highly varied species distribution (Wang et al, 2016).

Pereira et al. (2008) investigated the occurrence of Aeromonas in 2,323 samples of rectum swabs of newly born children hospitalized in Rio de Janeiro, and revealed a $94.6 \%$ prevalence of Aeromonas, featuring A. caviae, A. veronii biovar sobria, A. hydrophila, A. veronii biovar veronii, A. sobria, A. jandaei and $A$. scubertii. A. caviae was the most prevalent sample (42.8\%) among the species and $26.8 \%$ of strains were resistant to antibiotics and antimicrobial drugs.

A gastroenteritis outbreak occurred in a faculty in Xingyi, China, in 2012, and notified at the Guizhou Center for the Control and Prevention of Diseases. The clinical examination of two hundred students indicated Aeromonas hydrophila as the etiological agent, possibly caused by the intake of salads contaminated by water (ZHANG et al., 2012).

The best way to avoid contamination either by contaminated food or by crossed contamination is good handling practices plus adequate sanitation of utensils. Human exposure to these diseases may be thus avoided or minimized. People in direct contact with fish, such as fish farm laborers, fish sellers and amateur anglers, are greatly exposed to the pathogenic agent since certain Aeromonas species are pathogenic to humans. The handling of the products should be done with care since fish may be infected by $A$. hydrophila strains that may cause infections on the skin (GONZALEZSERRANO et al., 2002: SILVA et al., 2010).

Studies on frozen and fresh fish have identified Aeromonas strains. Consequently, strains of the bacterium may be retrieved from frozen food. They also reported that bacteria may be related to the deterioration process of fresh and frozen fish (GONZALEZ, SERRANO et al., 2001). A research in the state of São Paulo, Brazil, assessed the microbiology of salmon by quantifying microorganisms in the flesh of 31 frozen and cooled samples and reported Aeromonas ssp. and other microorganisms. Nespolo et al. (2012) analyzed the retail market in towns of the state of São Paulo, Brazil, and detected Aeromonas ssp. in $41.95 \%$ of the samples, with a population variation ranging between $2.0 \times 102$ and $8.0 \times 103 \mathrm{CFU} / \mathrm{g}$. Further, another study in the state of Rio 
Grande do Sul, Brazil, analyzed the occurrence of Aeromonas hydrophila and Campylobacter jejuni in fresh tuna samples (Thunnus spp.), caught on the coast of the state of Santa Catarina, Brazil. The authors evaluated 85 tuna fillet samples processed by bacteriological and PCR analyses. Eleven (13\%) out of 85 samples (13\%) were positive for Aeromonas spp., or rather, $10(90.9 \%)$ were Aeromonas hydrophila by PCR (COSTA, 2016; NESPOLO, 2012). The sawfish is contaminated by A. hydrophila and may propagate the agent when consumed (FERREIRA et al., 2014). The assay collected 60 samples of live common carps and frozen fish from 15 markets in Bagdad, Iraq, to isolate Aeromonas hydrophila and determine the hemolytic and cytotoxic activities of isolates and their susceptibility to antibiotics. Further, 65\% of samples were positive for Aeromonas hydrophila: $76.6 \%$ in samples of fresh fish and $53.3 \%$ in frozen fish. Moreover, $94.87 \%$ revealed hemolysis $\alpha$ and $\beta ; 100 \%$ of live fish showed $\beta$ hemolysis, whereas $85.7 \%$ frozen fish revealed $\beta$ hemolysis and $14.3 \% \alpha$ hemolysis; $97.43 \%$ of isolates proved to be cytotoxic to vero cells, with $60.50 \%$ the highest frequency rate in fish group isolates. All isolates were totally resistant to penicillin, ampicillin, cloxacillin and bacitracin in the sensitivity tests, and resistant to other antibiotics, such as oxytetracylin, with $56.5 \%$, tetracyclin, with $33.4 \%$, cefoxetin with $30.8 \%$, chloramphenicol and canamycin $28.2 \%$. Isolates were resistant to streptomycin and rifampicin respectively at $23.1 \%$ and $15.4 \%$. Results showed the occurrence of Aeromonas hydrophila with multiple resistance to antibiotics in fish from the Bagdad markets (ALZAINY, 2011). Belém-Costa \& Cyrino (2006) isolated $A$. hydrophila strains which were resistant to antibiotics in fish samples and concluded that excessive use of drugs in Brazilian fish farms may contribute towards bacteria resistance in native fish.

Four species of Aeromonas sp., namely, A. hydrophila, A. caviae, A. veronii sobria, and A. schuberti, occurred in all samples in catch-and-buy farms in the state of Maranhão, Brazil. The authors concluded that fish farms may transmit pathogenic Aeromonas and thus become a risk factor for consumers of fish farmed on the farms (SILVA et al., 2010). Aeromonas are the cause of gastroenteritis. The disease is transmitted to humans by contact with the etiological agents and by the intake of contaminated meat, vegetables and water. Several studies have in fact related the Aeromonas-caused infection (gastroenteritis) as one of the causes of traveler's disease (VILA, et al., 2003; 
TAVARES et al., 2015).

In Thailand, Aeromonas hydrophila is a free bacterium which causes diseases in fish. The organism is an opportunist pathogen in man. It seems that the first reported occurrences of $A$. hydrophilacaused infections in animals and humans in Thailand were respectively in 1976 and 1979, with fish mortality ranging between 0 and $20 \%$. In the case of human infection, diarrhea is predominant (SAITANU, 1986). Vila et al. (2003) reported that $A$. veronii sobria and A. caviae are Aeromonas species which are greatly associated with traveler's diarrhea. Pereira et al. (2008) studied the presence of Aeromonas in newly born children hospitalized in Rio de Janeiro and revealed a $94.6 \%$ prevalence for Aeromonas, with a $42.8 \%$ prevalence for $A$. caviae.

Traveler's diarrhea is one of the commonest health problems for international travelers. Spanish studies at the Unit for Tropical Medicine of the Clinical Hospital of Barcelona during the 1999-2001 period, on 863 samples, undertaken to determine the prevalence of Aeromonas in patients suffering from traveler's diarrhea, showed that the pathogen was the cause of traveler's diarrhea in $2 \%(n=18)$ of the samples. The species $\quad$. veronii sobria, $A$. caviae, $A$. jandai and $A$. hydrophila were isolated from the samples (VILA, et al., 2003).
A Brazilian study on a diarrhea outbreak in São Bento do Uma PE Brazil, in 2004, with 2,170 reported cases, revealed that $145(25 \%)$ out of 582 stool tests were caused by the bacterial enteropathogen, with 114 cases (19.5\%) caused by Aeromonas. When analyzed by gender, Aeromonas spp. was prevalent in females (54-59.3\%), with the most hit age bracket between 1 and 5 years (50-34.4\%). The species A. caviae $(57 ; 9.8 \%), A$. veronii biovar sobria $(23 ; 3.9 \%)$ and $A$. veronii biovar veronii $(15 ; 2.6 \%)$ were the most isolated species of the genus Aeromonas, greatly associated with diseases in humans (HOFER, et al., 2006).

\section{Virulence factors}

Although Aeromonas secrete several toxins which generally cause gastroenteritis, they may also damage the skin of infected people. In intestine infections, bacteria cause serious diarrhea and may become fatal if other body members, such as an open wound, are infected. The occurrence of the genus Aeromonas in animal-derived food has shown that, even with hygiene-sanitary control, its presence brings risk to the consumer's health (RIBEIRO, 2008; PEIXOTO et al, 2012; JANDA; ABBOTT, 2010; STRATEV et al., 2015).

Bacteria of the genus Aeromonas are relevant pathogenic microorganisms. Since they are bacteria derived from water 
and other environments, they may adapt themselves to a great variety of environments due to several virulence factors. This fact is directly linked to the microorganism's pathogenicity for humans (JANDA, 2010, MARTINELI, T. M. et al., 2011, SILVA 2014).In fact, water and food have an important role in the pathogen's propagation (PEIXOTO et al., 2012; TAVARES, 2015).

Owing to the great diversity of ecosystems in which Aeromonas may occur, they have become resistant to antimicrobials and demonstrate high virulence levels. The latter feature is due to the fact that several Aeromonas species secrete extracellular proteins, such as amylase, chitinase, elastase, aerolisin, nuclease, gelatinase, lecitinase, lipase and protease, known in the literature as virulence factors that cause disease in fish and humans (RODRÍGUEZ et al.,2007; NAM et al., 2007; MARTINELI et al., 2011).

Aeromonas spp. are bacteria capable of forming biofilms, which allows them in the water distribution system and on the surface of food processing and, finally, food (CRAVEIRO et al., 2015). Several studies hold that biofilms adhere efficiently to the gastrointestinal tract and increase the microorganism's pathogenicity (SANTOS et al., 2011; SCOARIS et al., 2008). Further,
Aeromonas also have the capacity of forming biofilms in stainless steel disks from different origins. The above is important in food processing milieus and underscore the relevance of cleaning procedures and disinfection of the sites (CARNEIRO et al., 2006; SCOARIS et al., 2008).

According to Puthucheary et al. (2012), the pathogenicity of the genus Aeromonas is related to several factors, among which may be mentioned thermolabile cytotonic enterotoxin (alt), thermostable cytotonic enterotoxin (ast), cytotoxic thermolabile enterotoxin (act), aerolisin, flagella $\mathrm{A}$ and $\mathrm{B}$, lipase, elastase and serine, protease (PUTHUCHEARY et al, 2012). Several studies have shown that any factor will determine the development of the bacterium-caused infection (TAVARES, 2015). Among 800 stool specimens in Spanish patients with diarrhea and submitted to analysis, thirtytwo (4\%) were positive for Aeromonas spp. Most had one or more virulence genes. Occurrence of genes alt, hlyA, aerA, ast and laf was respectively 71.9, 28.1, 25.0, 18.8 and 9.4\% (PABLOS et al., 2010).

Research on virulence of Aeromonas has shown their capacity in isolated strains from water and the environment and from wounds and stool from infected patients. A study on rats with 
regard to the importance of flagella and enterotoxins for the virulence of Aeromonas, evaluated 55 samples of drinkable water and 9 clinical isolated and reported 16 strains of Aeromonas hydrophila and 7 strains of Aeromonas veronii. Seven strains of Aeromonas caviae demonstrated different gene combination of the virulence factor in immunocompromised rats. Only the strains with one or more enterotoxins flaA, flaB and flaG or lafA revealed signs of virulence. Since the above association has been observed in $97 \%$ of the strains, one may conclude that Aeromonas isolates in water have pathogenic capacity for immunocompromised specimens (SEN, \& LYE, 2007).

A study undertaken between 2004 and 2011 in southern Taiwan showed that A. dhakensis is the species with the highest rate of occurrence among isolates from wounds. This type of Aeromonas is more virulent than A. hydrophila. It may also be said that $A$. dhakensis, frequently identified as A. hydrophila, phenotypically, is an important human pathogen and both may cause serious skin infection and on the soft tissues (CHEN et al., 2014).

Aravena-Román et al. (2014) reported that $96 \%$ of strains had at least one virulent gene. General distribution of virulent genes comprised aerA / haem $(77 \%)$, alt (53\%), lafA (51\%), ast (39\%),
flaA (32\%), aspA (29\%), vasH (26\%), ascV 16\%) and aexT (13\%). Further, out of the main species, $48 \%$ of $A$. hydrophila and $42 \%$ of $A$. dhakensis isolated five or more virulence genes, whereas $19 \%$ were isolated in A. veronii $b v$. Sobria and none in A. caviae isolates. Results show that in West Australia, strains of A. dhakensis and A. hydrophila are more virulent than those of A. veronii bv. Sobria and A. caviae.

Manna et al (2013) remark that gastroenteritis induced by Aeromonas ssp. is common in India. Enterotoxigenous Aeromonas in different uncooked and ready-made food are a serious menace to human health. Antimicrobial resistant $A$. hydrophila in food is a real threat in the health of land and aquatic animals (STRATEV \& ODEYEMI, 2015).

\section{Resistance to antimicrobial agents in} bacteria of the genus Aeromonas

A. hydrophila is a Gram-negative bacterium which have virulence factors, such as hemolysins, aerolysins, adesins and enterotoxins. Several studies have demonstrated that A. hydrophila has been isolated from beef, milk, milk derivates and vegetals. The species is resistant to commercial antibiotics, related to the indiscriminate use of antibiotics in fish farming and other aquatic food products by genetic mutations through plasmids or horizontal transference of genes. Since $A$. hydrophila is resistant to antimicrobial 
agents and it often occurs in food, it may be considered a menace to public health (STRATEV; ODEYEMI, 2015).

Martineli et al. (2010) evaluated bull carcass in the state of São Paulo and reported that 38 out of 285 samples were positive for Aeromonas spp. Antimicrobial resistance tests were performed. All isolates were resistant to ampicillin and cephalothin. Resistance to antimicrobial agents is a great concern since indiscriminate use may develop a multiresistant bacterium in the case of Aeromonas spp. This is more serious due to the fact that some species are pathogenic to humans. The authors of the abovementioned study warns on care that should be taken and brings forth the species A.caviae, prevalent in the assay, and one of the species described in the literature as the etiological agent of gastroenteritis in humans. Research on cheese has revealed all multi-resistant to the 15 antimicrobials tested in Aeromonas spp isolates. Results pinpoint a deep concern for public health (CERESER et al., 2013).

Assay performed in Malaysia have proved the resistance of the genus Aeromonas to antimicrobials. A 2015 study by Odeyemi \& Ahmad on Aeromonas strains derived from an aquatic environment revealed a multi-resistant pattern among isolates and 21 different phenotypes. All isolates were resistant to ampicillin, novobiocin, sulfametoxazol and trimethoprim. They were also sensitive to others, such as, tetracycline. Several researches have shown that the indiscriminate use of antibiotics may produce multi-resistant bacteria of the genus Aeromonas, or rather, a public health issue due to the existence of pathogenic species for humans and aquatic animals (ODEYEMI; AHMAD, 2013, 2014, 2015). Other assays show that some Aeromonas species are pathogenic and may be causing diarrhea. They should be included in routine bacteriologic tests (SENDEROVICH et al., 2012).

A study performed in Israel, featuring 1033 samples of diarrhea stool, evaluated the prevalence and virulence of Aeromonas by molecular methods. The etiological agent of 17 samples was Aeromonas spp. identified by sequencing rpoD gene. The first case of clinical report of diarrhea by Aeromonas taiwanensis was identified among the species. The species were resistant to beta-lactam antibiotics and had a susceptibility level to third generation cephalosporin antibiotics (SENDEROVICH et al., 2012; RUIZCASTILLO et al., 2016).

Several research works for the identification and characterization of strains $A$. sanarellii and A. taiwanensis identified chironomid egg masses in a residue lake in the same region where 
Senderovich et al. (2012) sequenced the rpoD gene for identification. Data do not forward the feature of virulence and antimicrobial resistance of the new species with pathogenicity for humans. Isolated $A$. sanarellii and A. taiwanensis underwent the susceptibility test for antimicrobial agents and proved to be sensitive to amicacin, aztreonam, cefepime, cephoxatime, cephthazidima, ciprofloxacin, gentamicin, piperacilintazobactam, tigeciclina, tobramycin, sulfametoxazol, trimethoprim and imipenem. According to the authors, the factor reveals how infections caused by these species could be attacked (BEAZHIDALGO et al., 2012).

Evangelista-Barreto et al. (2010) undertook a study on the river Cocó $\mathrm{CE}$ Brazil and detected Aeromonas, with the identification of $60 \%$ of the 38 strains evaluated: A. caviae, A. veronii bv. sobria, A. veronii bv. veronii, A. trota, A. media, A. sobria, A. hydrophila and Aeromonas $s p$. All strains were resistant to at least one tested antibiotic. Several species proved to be multi-resistant, with Aeromonas caviae as the most resistant (four antibiotics). Further, A. caviae is a pathogenic strain for humans and its occurrence in contaminated water and food may cause gastroenteritis to people within the risk bracket, such as children and immune-depressed people (LAVIAD; HALPERN, 2016).
Between 2006 and 2008, 154 samples of food ready for consumption were tested for Aeromonas spp in Mumbai, India. The study identified 18 (11.7\%) samples with 22 isolates of Aeromonas belonging to 7 different species. Isolated Aeromonas strains proved to be positive for virulence factors with high antimicrobial resistance and thus a risk for the health of people who intake the uncooked or cooked contaminated food (NAGAR et al., 2011).

Aeromonas strains are known for their enhanced capacity in acquiring and exchanging resistance genes against antibiotics. There is a high correlation between fish farming, Aeromonas diversity and resistance to antibiotics. There is a robust indication of links between the prophylactic and systemic use of antibiotics in fish farming and the spread of resistance against antibiotics (PALÚ et al., 2006; NAGAR et al., 2011).

\section{Brazilian legislation on fish}

Based on the microbiological standards by Brazilian legislation, one may perceive that the RDC n. 12 of 12/01/2001, which determined the microorganism standards for cooked fish and sea food, fresh or frozen, mention standards for positive coagulase staphylococci / g $10^{3}$, with $5 \times 10^{2}$, maximum at $10^{3}$; in the case of Salmonella spp. with $25 \mathrm{~g}$, insisting on total absence. This boils down to the fact that 
Brazilian legislation fails to give a microbiological standard for Aeromonas spp for this type of food (BRASIL, 2001).

In fact, there is no microbiological standard for this microorganism for any type of food (RODRIGUES, 2007).

According to Lanzarin et al. (2011), current legislation in Brazil does not define any limits for counts of psychrotrophic aerobic heterotrophic microorganisms for fresh fish. However, international legislation establishes the maximum limit of $7.0 \mathrm{log} / \mathrm{g}$. Further, several studies have shown that there are no minimum infectious doses for Aeromonas hydropila (ASSEGURAMENTO, 1997).

Resolution 357, published in 2005, determines that water for fish farming and fishing activities should not have more than 1000 thermotolerant coliforms /100 mL (SILVA et al., 2010; BRASIL, 2005). Although Brazilian legislation does not have any limits for total coliforms in fish, their presence in food should be investigated to guarantee the fish's sanitary quality. Several studies have detected total coliform rates above 50 and up to 100 MPN / $\mathrm{g}$ in fish, which is a matter of concern. Control measures should be undertaken with regard to these microorganisms (BRASIL, 2001; AGNESE et al., 2001).

Aeromonas are pathogenic bacteria which had been classified as emergent by
WHO. There is no legislation in Brazil that establishes parameters for the identification and quantification of the genus Aeromonas in food and water research. Other research works have shown that the genus is not routinely investigated. Even though it is not part of the roll of microorganisms specified by current environmental and sanitary legislation, its analysis on water and fish has great economic and sanitary relevance. In fact, the bacterium may cause liabilities for fish farming and serious diseases to humans. Damages are also associated with reduced shelf life due to high concentration rates of the bacteria (LANZARIN et al., 2011; BARBOSA, 2013).

Aeromonas infecting dose for humans has not been defined but research has shown that cooking may inactivate the bacteria. On the other hand, crossed contamination offers high risks to health, especially to people within the risk bracket, such as children, elderly people and immuno-depressed people. In fact, the microorganism has been often detected in stool from HGS-gastroenteritis (GONZALEZ et al., 2001; SILVA et al., 2010).

\section{References}

1. $3 \mathrm{M}$ and Petrifilm are trademarks of $3 \mathrm{M}$, used under license in Canada. AOAC is a registered trademark of AOAC international. Please recycle. Printed in U.S.A. (C) 3M 2014. Available at: 
<http://multimedia.3m.com/mws/media/24127 90/petrifilm-staph-express-brochure.pdf $>$. on 25/09/2016.

2. AGNESE, A. P.et al. Contagem de bactérias heterotróficas aeróbias mesófilas e enumeraçäo de coliformes totais e fecais, em peixes frescos comercializados no município de SeropédicaRJ. Hig. aliment, v. 15, n. 88, p. 67-70, 2001.

3. ALZAINY, ZAINAB AUN ALI. The occurrence, hemolytic, cytotoxic activity and antibiotic susceptibility of Aeromonas hydrophila isolated from fish samples in baghdad. Iraqi J Veterinary Sci, v. 35, p. 123-35, 2011.

4. ANDRADE, H.K .Impactos da aqüicultura no turismo / Humberto Ker de Andrade. - Vitória : Sebrae/ES, 2007. 74 p.: il., retrs.; $24 \mathrm{~cm}$. Available at: $<$ http://www.bibliotecas.sebrae.com.br/chronu s/ARQUIVOS CHRONUS/bds/bds.nsf/0296D 929E95196B0832573A30048910F/\$File/NT0 0037326.pdf > . on 19/01/2017.

5. ANDRIOTA, A.; GERONDI, G.; MARTOS, H.L. LEVANTAMENTO TURÍSTICO-AMBIENTAL DOS "PESQUE-PAGUE" DA REGIÃO DE CAMPINAS-SP. Available at: < http://docplayer.com.br/3545587-

Levantamento-turistico-ambiental-dos-pesquepague-da-regiao-de-campinas-sp.html $>$. On 19/01/2017.

6. APHA - American Public Health Association, Standard Methods for the Examination of Dairy Products, Washington D.C. 14th Ed., 1978.

7. APHA - Standard methods for the examination of water and wastewater.20.ed. Washington: American Public Health Association; 1998, 339p.

8. ARAVENA-ROMÁN, M. et al. Distribution of 13 virulence genes among clinical and environmental Aeromonas spp. in Western Australia. European journal of clinical microbiology \& infectious diseases, v. 33, n. 11, p. 1889-1895, 2014.

9. ASSEGURAMIENTO de La calidad de los productos pesqueros: FAO, Roma. 174p.
(Documento técnico de pesca, 334) 1997. Available

at:https://books.google.com.br/books?hl=pt-

BR\&lr=\&id=zg9Q-

ZvOO 0C\&oi=fnd\&pg=PA1\&ots=a5txFLrrO \&sig=7NTHsyAb7cVfC-

WsFlAZ2zuDdNU\&redir esc $=\mathrm{y} \# \mathrm{v}=$ onepage $\&$ $\mathrm{q} \& \mathrm{f}=$ false on 23/07/2016.

9. ASSUNÇÃO, A.W.A. Tratamento de efluentes de piscicultura utilizando sistema tipo wetland povoado com espécies de macrófitas aquáticas de três tipos ecológicos diferentes. 2011.

10. BARRETO, N.S.E. et al. Avaliação das condições higiênico-sanitárias do pescado comercializado no município de Cruz das Almas, Bahia. Revista Caatinga, v. 25, n. 3, p. 86-95, 2012.

11. BARROS, L.S.S.; CRUZ, C.R.; SILVA, V.C. Qualidade das águas de nascentes na bacia hidrográfica do rio Paraguaçu, Cruz das Almas, Bahia.Revista Brasileira de Recursos Hídricos.VOLUME. 20 - Nº 3 - JUL/SET 2015.

12. BARROS, L.S.S. et al. Estudo do potencial do impacto ambiental de águas residuárias de abatedouros avícolas e suinícolas. 2005.

13. BATISTA, A.S. et al. Escherichia coli O 157: H7 em leite produzido no Brasil. Revista Brasileira de Higiene e Sanidade Animal, v. 8, n. 2, p. 87-111, 2014.

14. BEAZ-HIDALGO, R. et al. Chironomid egg masses harbour the clinical species Aeromonas taiwanensis and Aeromonas sanarellii. FEMS microbiology letters, v. 337, n. 1, p. 48-54, 2012.

15. BRANDI, G. et al. Survival of Aeromonas hydrophila, Aeromonas caviae and Aeromonas sobria in soil. Journal of applied bacteriology, v. 81, n. 4, p. 439-444, 1996.

16. BRASIL. Ministério da Pesca e Aquicultura $\mathbf{1}^{\circ}$ anuário brasileiro da pesca e aquicultura do Brasil 2014 Available at < http://formsus.datasus.gov.br/novoimgarq/160 61/2489520_218117.pdf> on 27/01/2017. 
17. BRASIL. Fundação Nacional de Saúde. Manual prático de análise de água. $2^{\mathrm{a}}$ ed. rev. - Brasília: Fundação Nacional de Saúde, 2006.

18. BRASIL. Ministério da Saúde. Agência Nacional de Vigilância Sanitária. Resolução RDC $\mathrm{n}^{\circ}$ 12, de 02 de janeiro de 2001. Regulamento Técnico sobre Padrões Microbiológicos para Alimentos. Diário Oficial da República Federativa do Brasil, Brasília, DF, Seção 1, p. 45.10 jan. 2001.

19. BRASIL. Ministério da Saúde. Doenças Transmitidas por Alimentos. 2014. Available at: http://portalsaude.saude.gov.br/index.php/oministerio/principal/leia-mais-oministerio/653-secretaria-svs/vigilancia-de-aa-z/doencas-transmitidas-por-alimentosdta/11216-descricao-da-doenca; 15/03/2016.

19. BRASIL. Ministério da Saúde. Secretaria de Vigilância em Saúde - SVS. Doenças Transmitidas por Alimentos. 2015. Available at:

http://portalsaude.saude.gov.br/images/pdf/201 5/julho/01/arquivo-1-dta.pdf. on 20/07/2016.

13. BRASIL. Ministério do Meio Ambiente. Conselho Nacional do Meio Ambiente CONAMA (2005). Resolução ${ }^{\circ} 357$ de 17 de março de 2005. Dispõe sobre a classificação dos corpos de água e diretrizes ambientais para o seu enquadramento, bem como estabelece as condições e padrões de lançamento de efluentes, e dá outras providências. Diário Oficial da União, Brasília. Available at: $<$ http://www.mma.gov.br/port/conama/legiabre .cfm?codlegi=459 >. On 15/10/2016.

14. BRASIL. O PRESIDENTE DO INSTITUTO BRASILEIRO DO MEIO AMBIENTE E DOS RECURSOS NATURAIS RENOVÁVEIS - IBAMA. PORTARIA No 136/98, de 14 de OUTUBRO de 1998. Available at: < http://www.abrappesq.com.br/lei_portaria.htm >. on $15 / 10 / 2016$.

15. BRASIL. Portaria $\mathrm{n}^{\circ} 2.914$, de 12 de dezembro de 2011. O Ministério da Saúde aprova normas e padrões de potabilidade da água destinada ao consumo humano. Diário
Oficial, Brasília,14 dez. 2011, Seção 1, p.3946.

16. BRABO, M.F. et al. Cenário atual da produção de pescado no mundo, no Brasil e no estado do Pará: ênfase na aquicultura/Current scenario of fish production in the world, Brazil and Pará State: emphasis on aquaculture. Acta of Fisheries and Aquatic Resources, v. 4, n. 2, p. 50-58, 2016.

17. BRILHANTE, C.S. et al. Análise microbiológica e físico-química da água de bebedouros utilizados em escolas públicas na cidade de Coremas-PB.INTESA Informativo Técnico do Semiárido(PombalPB), v.10, n 1, p 05-08, Jan - Jun , 2016.

18. BUCKALEW, D. W. et al. A long-term study comparing membrane filtration with Colilert ${ }^{\circledR}$ defined substrates in detecting fecal coliforms and Escherichia coli in natural waters. Journal of environmental management, v. 80, n. 3, p. 191-197, 2006.

BUCKALEW, D. W. et al. IDEXX Summary 6Q. Journal of Environmental Management, v. 80, p. 191-197, 2006.

19. CAMPOS, L.C.;FRANZOLIN, M.R.; TRABULSI, L.R. Diarrheagenic Escherichia coli categories amons the tradicional enteropathogenic $E$. coli $\mathrm{O}$ serogroups. Memórias do instituto Oswaldo Cruz v. 9,n.6,p545552, 2004.

20. CAMPOS, J.L.; Produção Aquícola 2016. Panorama da AQÜICULTURA, vol. $23 \mathrm{n}^{\circ}$ 163, setembro/ outubro, 2017. Available at: < http://www.ferrazmaquinas.com.br/uploads/co nteudo/conteudo/2017/11/MHb2c/materiapanorama-produ-aquicola2016.pdf $>$. On $19 / 01 / 2018$.

21. CARDOSO, A.L.S.P. et al. Pesquisa de Salmonella spp, coliformes totais, coliformes fecais, mesófilos, em carcaças e cortes de frango. Hig. aliment, v. 19, n. 128, p. 144-150, 2005.

22. CARNEIRO, M.S.; JUNIOR, O.D.R. Bactérias do gênero Aeromonas no fluxograma de beneficiamento do leite tipo e seu comportamento frente à ação de 
antimicrobianos. Arq. Inst. Biol., São Paulo, v. 73, n. 3, p. 271-276, 2006.

23. CARVALHO, A.C.F.B.; CORTEZ, A.L.L.; SALOTTI, B.M.; BÜRGER, K.P.; VIDAL-MARTINS A.M.C. Presença de microrganismos mesófilos, psicrotróficos e coliformes em diferentes amostras de produtos avícolas Arq. Inst. Biol., São Paulo, v.72, n.3, p.303-307, jul./set., 2005.

24. CASTRO, P.M.G.;MARUYAMA, L.S.; de MENEZES, L.C.B.;MERCANTE, C.T. J. Perspectivas da atividade de pesqueiros no Alto Tietê: contribuição à gestão de usos múltiplos da ÁGUA. B. Inst. Pesca, São Paulo, 32(1): 1 - 14, 2006. Available at:<ftp://ftp.sp.gov.br/ftppesca/32_1_1-14.pdf $>$ on $16 / 01 / 2017$.

25. CAVALETT, O.;RODRIGUEZ,E. O.; QUEIROZ, J.F.; JÚNIOR, O.T.; CASACA, J.M. Análise emergética da piscicultura integrada a criação de suínos. Cadernos de Agroecologia.v. 1, n. 12006.

26. CERESER, N.D. et al. Resistance profile of Aeromonas spp. isolated in dairy products industry. Ars Veterinaria, v. 29, n. 1, p. 3036, 2013.

27. CHAN, F.K.L. et al. Aeromonas infection in acute suppurative cholangitis: review of 30 cases. Journal of Infection, v. 40, n. 1, p. 69$73,2000$.

28. CHEN, P.L. et al. A comparative study of clinical Aeromonas dhakensis and Aeromonas hydrophila isolates in southern Taiwan: A. dhakensis is more predominant and virulent. Clinical Microbiology and Infection, v. 20, n. 7, p. O428-O434, 2014.

29. COSTA, A.M., CARVALHO, A.F., FREDRIGO, R.C., KOBAYASHI, P.F., \& PINHEIRO, E.S. Detecção de Aeromonas hydrophila e Campylobacter jejuni em atum (Thunnus spp.) fresco comercializado em São Paulo, Brasil. Brazilian Journal of Veterinary Research and Animal Science, v. 53, n. 1, p. 48-54, 2016.

30. COSTA, T.D. et al. Qualidade microbiológica de tilápias obtidas de pesqueiros no interior do Estado de São Paulo,
Brasil . Ciência \& Tecnologia: FATEC-JB, Jaboticabal (SP), v. 8, Número Especial, 2016.

31. CRAVEIRO, SARA et al. Aeromonas biofilm on stainless steel: efficiency of commonly used disinfectants. International Journal of Food Science \& Technology, v. 50, n. 4, p. 851-856, 2015.

32. DA COSTA RENOVATO, D.C.;SENA,C. P. S.; SILVA M.M.F. Análise de parâmetros físico-químicos das águas da barragem pública da cidade de pau dos ferros (rn)-ph, cor, turbidez, acidez, alcalinidade, condutividade, cloreto e salinidade. In: IX Congresso de Iniciação Científica do IFRN. 2013.

33. DE ASSIS, F.S. et al. Avaliação das condições higiênico-sanitárias dos quiosques instalados na Companhia de Entrepostos e Armazéns Gerais do Estado de São Paulo (CEAGESP). Segurança Alimentar e Nutricional, v. 18, n. 2, p. 33-52, 2011.

34. DE JESUS RODRIGUES, $M$. et al. Escherichia coli O 157 in curd cheese. African Journal of Agricultural Research, v. 11, n. 5, p. 407-415, 2016.

35. DE OLIVEIRA, A.B.A. et al. Doenças Transmitidas por Alimentos: Principais Agentes Etiológicos, Alimentos Envolvidos e Fatores Predisponentes. Clinical \& Biomedical Research, v. 30, n. 3, 2010.

36. DE OLIVEIRA SARTORI, A.G.; AMANCIO, R.D. Pescado: importância nutricional e consumo no Brasil. Segurança alimentar e nutricional, v. 19, n. 2, p. 83-93, 2012.

37. DE PAIVA SOARES, K.M. et al. Pesquisa de Staphylococcus aureus em tilápia do nilo armazenada em gelo. Acta veterinária Brasilica, v. 6, n. 3, p. 239-242, 2012.

38. DE SOUSA LIMA, C.P. et al. Presença de microrganismos indicadores de qualidade em farinha e goma de mandioca (Manihot esculenta, Crantz). Revista APS, v. 10, n. 1, p. 14-19, 2007.

39. ELER, M.N.; MILLANI, Thiago José. Sustainable development in aquiculture: methodology and strategies. Revista 
Brasileira de Zootecnia, v. 36, p. 33-44, 2007.

40. EUZÉBY, J.P. NOTE. International Journal of Systematic and Evolutionary Microbiology, v. 48, n. 2, p. 613-613, 1998.

41. EVANGELISTA-BARRETO, N.S. et al. Characterization of Aeromonas species isolated from an estuarine environment. Brazilian Journal of Microbiology, v. 41, n. 2, p. 452-460, 2010.

42. FAO. FOOD AND AGRICULTURE ORGANIZATION OF THE UNITED NATIONS. Farming the waters for people and food. Proceedings of the Global Conference on Aquaculture. Disponível em , 2010.

43. FAO-FOOD AND AGRICULTURE ORGANIZATION OF THE UNITED NATIONS (FAO). Garantia da qualidade dos produtos da pesca. Fisheries and Aquaculture Department.2011. Available at: <http://www.fao.org/docrep/003/t1768p/T1768 P03.htm >. On 20/01/2017.

44. FAO. FOOD AND AGRICULTURE ORGANIZATION OF THE UNITED NATIONS.The State of World Fisheries and Aquaculture 2014. Rome. 223 pp.2014.

45. FAO. FOOD AND AGRICULTURE
ORGANIZATION OF THE UNITED NATIONS.The State of World Fisheries and Aquaculture 2016 (SOFIA) 204 pp. 2016.

46. FDA .The Bad Bug Book: Foodbourne Pathogenic Microorganisms and Natural Toxins Handbook. U.S Food and Drug Administration Web site 2009. Available at: $<$ http://www.fda.gov/downloads/Food/Food borneIllnessContaminants/UCM297627.pdf $>$ on $23 / 04 / 2016$.

47. FERNANDES, G.T.; RODELA, L.G. Aspectos Ambientais em Pesqueiro (pesquepague) DA Região de Juquitiba, estado de São Paulo. Ciências Biologicas . III Seminário Nacional de Pesquisa, 2009.

48. FERNANDES, R.; GOMES, L.C.; AGOSTINHO, A.A. Pesque-pague: negócio ou fonte de dispersão de espécies exóticas?-
. Acta Scientiarum. Biological Sciences, v. 25, n. 1, p. 115-120, 2008.

49. FERNANDES, L.L.; GOIS, R.V. Avaliação das Principais Metodologias Aplicadas às Análises Microbiológicas de Água para Consumo Humano Voltadas para a Deteç̧ão de Coliformes Totais e Termotolerantes. Revista Científica da Faculdade de Educação e Meio Ambiente 6(2): 49-64, jul-dez, 2015.

50. FERREIRA, E.M. et al. Microbiological quality of the fish saw (Scomberomorus brasiliensis) and the ice used for its conservation. Arquivos do Instituto Biológico, v. 81, n. 1, p. 49-54, 2014.

51. FIORENTINI, C. et al. Occurrence, diversity and pathogenicity of mesophilic Aeromonas in estuarine waters of the Italian coast of the Adriatic Sea.Journal of Applied Microbiology, v. 85, n. 3, p. 501-511, 1998.

52. FRANCO BDGM, L.M. Microbiologia dos alimentos. São Paulo: Atheneu; 2004.

53. FUNASA. Ministério da Saúde (BR). Manual Prático de Análise de Água. 2. ed. Brasília (DF): Assessoria de Comunicação e Educação em Saúde, 2006.

54. GERMANO P.M.L.; GERMANO M.I.S. Higiene e vigilância sanitária de alimentos. 3. ed. São Paulo: Manole; 2008.

55. GONÇALVES, S.L.S.G. P et al. Avaliação da qualidade microbiológica de produtos prontos a consumir. 2012. Doctoral Thesis. Escola Superior de Hotelaria e Turismo do Estoril.

56. HENRIQUES, K.R.S. Detecção DE Coliformes Totais e Escherichia coli em Água de Consumo Humano pelo Método Colilert. UNIVERSIDADE ESTADUAL DA PARAÍBA - UEPB. Campina Grande - PB Outubro de 2010.

57. HERNOULD, $M$. et al. Role of the AheABC efflux pump in Aeromonas hydrophila intrinsic multidrug

resistance. Antimicrobial agents and chemotherapy, v. 52, n. 4, p. 1559-1563, 2008 . 
58. HOFER, E. et al. Aeromonas associated with an acute diarrhea outbreak in São Bento do Una, Pernambuco. Revista da Sociedade Brasileira de Medicina Tropical, v. 39, n. 2, p. 217-220, 2006.

59. IBGE. Abate de animais, produção de leite, couro e ovos. Available at: http://www.ibge.gov.br/home/estatistica/indica dores/agropecuaria/producaoagropecuaria/abat e-leite-couro-ovos 201403 4.shtm; on $14 / 03 / 2016$.

60. IBGE-Instituto Brasileiro de Geografia e Estatística - Produção da Pecuária Municipal Prod. Pec. munic., Rio de Janeiro, v. $42, \quad$ p.1-39, 2014. Available at: $<$ http://biblioteca.ibge.gov.br/visualizacao/p eriodicos/84/ppm_2014_v42_br.pdf $>$ on 24/04/2016.

61. IBGE-Instituto Brasileiro de Geografia e Estatística - Produção da Pecuária Municipal Prod. Pec. munic., Rio de Janeiro, v. 44, p.1-39, 2016. Available at $<$ https://biblioteca.ibge.gov.br/visualizacao/per iodicos/84/ppm_2016_v44_br.pdf >. On 24/04/2018.

62. IDEXX (2002). Colilert ${ }^{\circledR}$. Um teste simples de 24 horas para coliformes $e$ E. coli. [Versão Eletrónica]. Available at: $<$ http://recife.ifpe.edu.br/recife/Colilert_Port ugu s.pdf. $>$ on 10/06/2016.

63. IGBINOSA, I.H. et al. Emerging Aeromonas species infections and their significance in public health. The Scientific World Journal, v. 2012, 2012.

64. JANDA, J.M.; ABBOTT, S.L. The genus Aeromonas: taxonomy, pathogenicity, and infection. Clinical microbiology reviews, v. 23, n. 1, p. 35-73, 2010.

65. KATSUYA, E.M. et al. Escherichia coli O157: H7, um enteropatógeno emergente. SIMPÓSIO DE SEGURANÇA ALIMENTAR E SAÚDE DO ESTADO DE SÃO PAULO, v. 1, p. 815-818, 1998.

66. KUBITZA, F; CAMPOS, J.L.; ONO, E.A.; ISTCHUK, P.I. Panorama da piscicultura no Brasil parte I estatísticas, espécies, pólos de produção e fatores limitantes à expansão da atividade. Panorama da AQÜICULTURA, vol. $22 \mathrm{n}^{\circ}$ 132, julho, agosto, 2012.

67. KUBITZA, F.P.H.D. Aquicultura no Brasil principais espécies, áreas de cultivo, rações, fatores limitantes e desafios. Panorama da AQÜICULTURA, vol. $25 \mathrm{n}^{\circ}$ 150, julho, agosto, 2015.

68. LANZARIN, M. et al. Occurrence of Aeromonas sp. and psychrotrophic microorganisms and estimate the shelf life of" pintado"(Pseudoplatystoma coruscans) fillets kept under refrigeration. Arquivo Brasileiro de Medicina Veterinária e Zootecnia, v. 63, n. 6, p. 1541-1546, 2011.

69. LATIF-EUGENÍN, F.; BEAZ-HIDALGO, R.; FIGUERAS, M.J. First record of the rare species Aeromonas schubertii from mussels: phenotypic and genetic reevaluation of the species and a review of the literature. Archives of microbiology, v. 198, n. 4, p. 333-345, 2016.

70. LAVIAD, S.; HALPERN, M. Chironomids' Relationship with Aeromonas Species. Frontiers in microbiology, v. 7, 2016.

71. LIBERATO, F.R.; SHIKIDA, A.S.R.L. Segurança alimentar: Um estudo multidisciplinar de qualidade do filé de tilápia comercializado no município de ToledoPR. Revista do Grupo de Pesquisa em Agronegócio e Desenvolvimento Regional (GEPEC) da UNIOSTE, v. 9, n. 2, 2005.

72. LORENZON, C.S. et al. COMUNICAÇÃO Científica perfil microbiológico de peixes e água de cultivo em pesque-pagues situados na Região Nordeste do Estado de São Paulo. Arq. Inst. Biol., São Paulo, v. 77, n. 4, p. 617-624, 2010.

73. MACEDO, C.F.; SIPAUBA-TAVARES, L.H. Eutrofização e qualidade da água na piscicultura: consequências e recomendações. Bol. Inst. Pesca, v. 36, n. 2, p. 149-163, 2010.

74. MACEDO, D.S.; MARTINS, M.L.; WEBER, M.L. Identificação das condições higiênico-sanitárias na comercialização de 
peixes em feiras livres na zona sul de São Paulo. Life Style, v. 2, n. 1, p. 23-30, 2015.

75. MACHADO, T.M. et al. Fatores que afetam a qualidade do pescado na pesca artesanal de municípios da costa sul de São Paulo, Brasil. Boletim do Instituto de Pesca, v. 36, n. 3, p. 213-223, 2010.

76. MANNA, SANJIB KUMAR et al. Occurrence and virulence characteristics of Aeromonas species in meat, milk and fish in India. Journal of Food Safety, v. 33, n. 4, p. 461-469, 2013.

\section{MARQUEZ, I.M.C. Comparação} metodológica para a estimativa do número mais provável (NMP) de coliformes em amostras de água. 2010. 111 f. Master's Dissertation in Food Science and Technology) - Universidade de São Paulo, Escola Superior de Agricultura Luiz Queiroz. 2010. Available at: on $30 / 04 / 2015$.

78. MARTINELI,T.M. et al. Ocorrência de Aeromonas spp.em abatedouro bovino e sensibilidade a antimicrobianos. Arq. Inst. Biol., São Paulo, v.77, n.2, p.195-202, abr./jun., 2010.

79. MARTINELI, T.M. et al. Estudo epidemiológico das Aeromonas spp., através de REP e ERIC-PCR, em abatedouro bovino. Arquivos do Instituto Biológico, v. 78, n. 4, p. 485-491, 2011.

80. MARTINO, M.E. et al. Determination of microbial diversity of Aeromonas strains on the basis of multilocus sequence typing, phenotype, and presence of putative virulence genes. Applied and environmental microbiology, v. 77 , n. 14 , p. 4986-5000, 2011.

81. MENG, J.; FENG, P.; DOLE, M.P.Pathogenic Eschericgia coli. In: Downes, f.p.; Ito, k. (eds). Compendium of methods for the Microbiological examination of Foods. 4 ed.) . American Public Health Association, Washington. D.C., USA, p.331-341.2001.

82. MERCANTE, C.T.J. et al. Water quality in fee-fishing ponds located in the metropolitan region of São Paulo city, Brazil: an analysis of the eutrophication process. Acta Limnologica Brasiliensia, v. 16, n. 1, p. 95-102, 2004.

83. MESQUITA, F.R. Análise físico-química e microbiológica da água: estudo de caso no balneário igarapé preto, Cruzeiro do Sul, Acre, Brasil. ENCICLOPÉDIA BIOSFERA, Centro Científico Conhecer - Goiânia, v.10, n. 19; p. 2014.

84. MUGG, P.; HILL, A. Comparison of the Microbact-12E and 24E systems and the API$20 \mathrm{E}$ system for the identification of Enterobacteriaceae. Journal of Hygiene, v. 87, n. 02, p. 287-297, 1981.

85. MUKHOPADHYAY, C. et al. Emerging extra-intestinal infections with Aeromonas hydrophila in coastal region of southern Karnataka. Journal of postgraduate medicine, v. 54, n. 3, p. 199, 2008.

86. MURATORI, M.C.S. et al. Escherichia coli e Staphylococcus aureus em Manipuladores de Piscicultura. Revista Científica de Produção Animal, v. 9, n. 2, 2007.

87. NAGAR, V.; SHASHIDHAR, R.; BANDEKAR, J.R. Prevalence, characterization, and antimicrobial resistance of Aeromonas strains from various retail food products in Mumbai, India. Journal of food science, v. 76, n. 7, p. M486-M492, 2011.

88. NAM, I.; JOH, KISEONG. Rapid detection of virulence factors of Aeromonas isolated from a trout farm by hexaplexPCR. JOURNAL OF MICROBIOLOGYSEOUL-, V. 45, N. 4, P. 297, 2007.

89. NESPOLO, N.M.; MARTINELI, T.M.; ROSSI J.R.; OSWALDO,D. Microbiological quality of salmon (Salmo salar) sold in cities of the state of São Paulo, Brazil. Brazilian Journal of Microbiology, v. 43, n. 4, p. 13931400, 2012.

90. ODEYEMI, O.A.; AHMAD, A. Antibiogram and resistogram profiling of Aeromonas species isolated from Malaysian aquatic sources. J. Coastal Life Med, v. 1, p. 108-112, 2013. 
91. ODEYEMI, O.A.; AHMAD, A. Antibiogram and resistogram profiling of Aeromonas species isolated from Malaysian coastal seawater. Pollution Research, v. 33, n. 2, p. 487-492, 2014.

92. ODEYEMI, O.A.; AHMAD, A. Antibiotic resistance profiling and phenotyping of Aeromonas species isolated from aquatic sources. Saudi Journal of Biological Sciences, 2015.

93. OLIVEIRA, C.F.P. M. Aplicação do Colilert ${ }^{\circledR}$ à enumeração de Escherichia coli em alimentos. 2013. Doctoral thesis.

94. OTTAVIANI, D. et al. Putative virulence properties of Aeromonas strains isolated from food, environmental and clinical sources in Italy: a comparative study. International journal of food microbiology, v. 144, n. 3, p. 538-545, 2011

95. PABLOS, M. et al. Occurrence of motile Aeromonas in municipal drinking water and distribution of genes encoding virulence factors.International journal of food microbiology, v. 135, n. 2, p. 158-164, 2009.

96. PABLOS, M. et al. Identity, virulence genes, and clonal relatedness of Aeromonas isolates from patients with diarrhea and drinking water. European journal of clinical microbiology \& infectious diseases, v. $29, n$. 9, p. 1163-1172, 2010.

97. PALÚ, ANGELA PERES et al. Antimicrobial resistance in food and clinical Aeromonas isolates. Food microbiology, v. 23, n. 5, p. 504-509, 2006.

98. PARRON, L.M.; MUNIZ, D.H.F.; PEREIRA, C.M. Manual de procedimentos de amostragem e análise físico-química da água. Colombo: EMBRAPA Florestas, 2011.

99. PEIXE - BR, Associação Brasileira de Piscicultura, Segunda edição do "Anuário Peixe BR", versão 2018. Available at <http://www.aquaculturebrasil.com/2018/02/1 9/peixe-br-lanca-o-anuario-da-piscicultura2018/ >. On 24/04/2018.
100. PEIXOTO, L.J.S. et al. Aeromonas spp.: virulence factors and resistance patterns to antimicrobial and heavy metals. Arquivos do Instituto Biológico, v. 79, n. 3, p. 453-461, 2012.

101. PEREIRA, C.S. et al. Characterization of Aeromonas spp isolates from newborns hospitalized. Revista da Sociedade Brasileira de Medicina Tropical, v. 41, n. 2, p. 179-182, 2008.

102. PIOTROWSKA, M.; POPOWSKA, M. Insight into the mobilome of Aeromonas strains Front Microbiol.; 6: 494.2015.

103. PIVELI, R.P. CURSO:"QUALIDADE DAS ÁGUAS E POLUIÇÃO: ASPECTOS FÍSICO-QUÍMICOS". Available at: $<$ http://www.leb.esalq.usp.br/disciplinas/Fern ando/leb360/Fasciculo\%2010\%20-

\%200xigenio\%20Dissolvido\%20e\%20Materia Organica.pdf >.on 05/04/2000.

104. PUTHUCHEARY, S. D.; PUAH, Suat Moi; CHUA, Kek Heng. Molecular characterization of clinical isolates of Aeromonas species from Malaysia. PloS one, v. 7, n. 2, p. e30205, 2012.

105. QUESADA, O.; ARIAS, M. L.; CHAVES, C. Efecto del horno de microondas sobre el crecimiento y sobrevivencia de Escherichia coli O157: H7 inoculada en tortas de carne de res. Archivos latinoamericanos de nutricion, v. 53, n. 1, p. 65-69, 2003.

106. RIBEIRO, M.E.A. Caracterização de Aeromonas spp. Isoladas de Águas não Tratadas para Consumo Humano. 2008.

107. RITTER, D.O.;LANZARIN, M. ; MELLO, C.A. ; ALMEIDA FILHO, E.S. Qualidade bacteriológica de cacharas (Pseudoplatystoma fasciatum) provenientes de piscicultura . ENCICLOPÉDIA BIOSFERA, Centro Científico Conhecer, Goiânia, v.8, n. $15 ;$ p. 2012.

108. ROCHA, F.A.G. et al. Estafilococos coagulase positivos em filés de tilápia (Oreochromis niloticus) comercializados no mercado modelo Nerival Araújo, Currais Novos/RN HOLOS, v. 29, n. 1, p. 84, 2013. 
109. RODRIGUES, E. Pesquisa de aeromonas spp. em tilápia (Oreochromis niloticus), cultivada no estado do Rio de Janeiro-Brasil: isolamento, identificação de espécies e avaliação da sensibilidade antimicrobiana. Doctoral Thesis. Universidade Federal Fluminense, Rio de Janeiro, Brasil.2007.

110. RODRIGUEZ LEC, et al. Factores de virulência en cepas de Aenomonas spp. aisladas de pacientes con bacteriemia Rev Panam Infectol ;9(4):19-23, 2007.

111. RUIZ-CASTILLO, A. et al. Influência de la correcta identificación en la interpretación de las pruebas de sensibilidad en aislados de Aeromonas spp. productoras de bacteriemia. Enfermedades Infecciosas $\mathbf{y}$ Microbiología Clínica, v. 34, n. 2, p. 96-100, 2016.

112. SAITANU, K. Aeromonas hydrophila infections in Thailand. In: 1. Asian Fisheries Forum, Manila (Philippines), 26-31 May 1986. 1986.

113. SANTIAGO, J.A.S. et al. Bactérias patogênicas relacionadas à ingestão de pescados-revisão. Arquivos de Ciências do Mar, v. 46, n. 2, 2013.

114. SANTOS, A.L. et al. Staphylococcus aureus: visiting a strain of clinical importance. Jornal Brasileiro de Patologia e Medicina Laboratorial, v. 43, n. 6, p. 413423, 2007.

115. SANTOS, D.M. S. et al. Qualidade microbiológica da água e histopatologia de brânquias de peixes provenientes de pisciculturas do município de itapecuru-mirim, Estado do Maranhão. Acta Scientiarum Biological Sciences, v. 34, n. 2, p. 199-205, 2012.

116. SANTOS, P.G. et al. Association of Aeromonas caviae polar and lateral flagella with biofilm formation. Letters in applied microbiology, v. 52, n. 1, p. 49-55, 2011.

117. SCOARIS, D. et al. Virulence and antibiotic susceptibility of Aeromonas spp. isolated from drinking water. Antonie Van Leeuwenhoek, v. 93, n. 1-2, p. 111-122, 2008.
118. SCURACCHIO, P.A.; FARACHE FILHO, A. Qualidade da água utilizada para consumo em escolas e creches no município de SÃO CARLOS-SP. Alimentos e Nutrição Araraquara, v. 22, n. 4, p. 641-647, 2012.

119. SEBRAE, Serviço Brasileiro de Apoio às Micro e Pequenas Empresas. Arquicultura no Brasil Série Estudos Mercadológicos.2015. Available at: http://www.bibliotecas.sebrae.com.br/chronus/ ARQUIVOS_CHRONUS/bds/bds.nsf/4b14e85 d5844cc99cb32040a4980779f/\$File/5403.pdf. on19/01/2017.

120. SEN, KEYA; LYE, Dennis. Importance of flagella and enterotoxins for Aeromonas virulence in a mouse model. Canadian journal of microbiology, v. 53 , n. 2 , p. 261$269,2007$.

121. SENDEROVICH, Y. et al. A molecular study on the prevalence and virulence potential of Aeromonas spp. recovered from patients suffering from diarrhea in Israel. PloS one, v. 7, n. 2, p. e30070, 2012.

122. SILVA, A.C.M.M. et al. Characterization of Aeromonas spp isolated from water and of oysters samples by microbiological and molecular methods. Ciência Animal Brasileira, v. 15, n. 3, p. 362-368, 2014.

123. SILVA, J.L.S. et al. Aquatic microbiota diversity in the culture of Nile tilapia (Oreochromis niloticus) using bioflocs or periphyton: virulence factors and biofilm formation. Acta

Scientiarum.Animal

Sciences, v. 38, n. 3, p. 233-241, 2016.

124. SILVA N, et al. Manual de métodos de análise microbiológica de alimentos e água. 4. ed., São Paulo: Ed. Varela; 2010.

125. SILVA, R.M.L. et al. Aeromonas spp. em água de piscicultura da região da baixada ocidental maranhense. Boletim do Instituto de Pesca, São Paulo, v. 36, n. 3, p. 245-249, 2010.

126. SILVEIRA, L.; MARQUES, A.; MACHADO, J. Patotipos de Escherichia coli associados a infeções entéricas entre 20022012. Artigos breves v.8. 2013. 
127. SOARES, K.M.P.; GONÇALVES, A.A. Qualidade e segurança do pescado. Rev Inst Adolfo Lutz. São Paulo, 2012; 71(1):1-10. 128. SOUSA, C.P. The impact of food manufacturing practices on food borne diseases. Brazilian Archives of Biology and Technology, v. 51, n. 4, p. 615-623, 2008.

129. SOUZA, G.M.D. et al. Análise da qualidade microbiológica da água, ao longo da cadeia produtiva de tilápia do nilo (Oreochromis niloticus), na Região Norte do estado do Paraná. Anais Eletrônico VII EPCC - Encontro Internacional de Produção Científica Cesumar 25 a 28 de Outubro de 2011

130. STRATEV, D.; ODEYEMI, O.A. Antimicrobial resistance of Aeromonas hydrophila isolated from different food sources: A mini-review.Journal of infection and public health, 2015

131. SUÁREZ, W.; HERRERA, F. Aislamiento de Aeromonas spp. en muestras de pescado fresco comercializado en Pamplona (Norte de Santander). Rev. U.D.C.A Act. \& Div. Cient. 14(2): 7 - 13, 2011.

132. TAVARES, A. B.; CERESER, N. D.; TIMM, C.D. Occurence of Aeromonas spp. in foods of animal origin and its importance in public health. Arquivos do Instituto Biológico, v. 82, p. 1-8, 2015.

133. TORRES, A.; ROSA, F.R.T.; ALENCAR, L. O efeito pesque e pague. AgroANALYSIS, v. 25 , n. 10 , p. 2627.2005.

134. VANDERZANT, C.; SPLITTSTOESSER, D.F. Compendium for the microbiological examination of foods. 3ed. Washington: American Public Health Association, 1219p, 1992.

135. VIANA, I.C.L. A.et al. Análise microbiológica do tambaqui (Colossoma macropoтum) comercializado na feira municipal de Ariquemes, Estado de Rondônia, Brasil. Revista Pan-Amazônica de Saúde, v. 7, n. 2, p. 67-73, 2016.
136. VIEGAS, E.M.M. et al. Métodos de abate e qualidade da carne de peixe. Archivos Zootecnia, v. 61, n. 1, 2012.

137. VILA, JORDI et al. Aeromonas spp. and traveler's diarrhea: clinical features and antimicrobial resistance.(Research). Emerging infectious diseases, v. 9, n. 5, p. 552-556, 2003.

138. VOLKWEIS, D.S.H. et al. Qualidade microbiológica da água utilizada na produção de alimentos por agroindústrias familiares do município de Constantina/RS. Electronic Journal of Management, Education and Environmental Technology (REGET), v. 19, n. 4, p. 18-26, 2015.

139. WANG WEN QING, PRIMAVERA WANG DUO, ZHULIN YING, FU YIFEI, HAOLI PENG, XUXUE BIN, SU JINGHUA, FUHUI QIN, folha limpa, os pacientes Sun Joe Zheng Yingjie. Shanghai Pudong Novo Espaço de Aeromonas com características epidêmicas diarreia e genes de virulência. Aeromonas. Jornal chinês de Epidemiologia,37 (3): 402405. 2016.

140. WU, C.J., WANG, H.C., CHEN, C.S., SHU, H.Y., KAO, A.W., CHEN, P.L., et al. Genome sequence of a novel human pathogen, Aeromonas aquariorum. Journal of Bacteriol. 194 4114-4115. 10.1128/JB.0062112, 2012.

141.ZHANG, Q. et al.A foodborne outbreak of Aeromonas hydrophila in a college, Xingyi City, Guizhou, China, 2012. Western Pacific Surveillance and Response Journal, v. 3, n. 4, p. 39-43, 2012. 